\title{
Association of religious coping use with psychological well-being of mother of mentally retarded children
}

\author{
Sak Liung, * Carla Raymondalexas Marchira, Irwan Supriyanto, Mahar Agusno, \\ Soewadi, Sumarni \\ Department of Psychiatric, Faculty of Medicine, Public Health, and Nursing, Universitas Gadjah Mada, \\ Yogyakarta, Indonesia
}

\section{Submitted: 27 June 2019 Revised: 24 August 2019 Accepted: 12 September 2019}

\begin{abstract}
S Low psychological well-being in mothers of children with mental retardation can affect maternal mental health and quality of life. Psychological well-being of mothers depend on maternal coping strategies to overcome the burden of childcare. The religious background of Indonesian society makes mothers tend to use religious coping in handling the burden of nurturing their children. Aim of this study to determine the association between religious coping use and psychological well-being of mothers of children with mental retardation. This is an analytic descriptive study with cross-sectional design. Subjects were mothers of children with mild to moderate level of mental retardation, students of SLB Negeri 1 Bantul. The psychological well-being and religious coping of mother is assessed by Indonesian version of the Psychological Well-being Scale and Religious Coping Scale. The significance level of the statistical test is expressed at $p<0.05$. Results of this study showed there is a significant association between religious coping and psychological well-being of mothers of children with mental retardation ( $X^{2}: 17.897 ; C: 0.377$; p: $0.000 ; \mathrm{RP}: 5.65 ; 95 \% \mathrm{Cl}: 2.46-12.92)$. All dimensions of religious coping have a significant association with the psychological well-being of the mother ( $p: 0.000)$. The dimensions of achieving comfort and closeness to God have the highest closeness association with the psychological well-being among other dimensions of religious coping $\left(X^{2}: 39.041 ; C: 0.515\right)$. The confounding variables in this study are mother's age, mother's education, family income, marital status, mother's employment status, family income, children's gender, children's level of mental retardation and children's class grade. Mother's education has also a significant association with the psychological well-being of the mother ( $p: 0.021)$. Religious coping and mother's education contribute $26.7 \%$ to the psychological well-being of mothers. This finding reveals that religious coping is important to improve the psychological well-being of mothers of children with mental retardation.
\end{abstract}

KEYWORDS mental retardation; mother; psychological well-being; religious coping

\section{Introduction}

Children with mental retardation need parental care in the long term. ${ }^{1}$ The process of caring for children with mental retardation can cause many difficulties for the mother as the primary caregiver of the child. ${ }^{2}$ This condition causes an increase in psychological burden, family problems, marital conflict, nurturing dissatisfaction and disruption

maternal health. ${ }^{3,4}$ Mothers who are stressed by high parenting experience adjustment failures and have an impact on the mother's psychological well-being. ${ }^{5,6} \mathrm{~A}$ study in Pakistan found that $56.8 \%$ of mothers of children with mental retardation have a low level of psychological well-being. ${ }^{7}$ Maternal parenting stress manifests in symptoms

\footnotetext{
*Corresponding author: Sak Liung

Department of Psychiatry, Faculty of Medicine, Public Health, and Nursing, Universitas Gadjah Mada, Jl. Farmako, Sekip Utara, Yogyakarta 55281, Indonesia

E-mail: dr.sakliung@gmail.com
} 
of depression, anxiety, and somatic higher than parents of normal children. ${ }^{18}$ Low psychological well-being is a predictor of the low quality of life of children with mental retardation and risk factors for maternal depression. ${ }^{9}$

Mother coping strategies will influence the adjustment process. The use of adaptive coping strategies will accelerate the process of acceptance of disability of children, reduce stress and improve psychological well-being of mothers. ${ }^{2,10} \mathrm{~A}$ mother who has a high level of psychological well-being is able to accept the conditions, always grateful for what is and having life satisfaction when given gifts children with mental retardation. ${ }^{11,12}$ Several factors that can affect the psychological well-being of the mothers, namely: age, gender, socio-economic status, marital status, personality, social relations, level of education, social support, children gender, chidren's level of mental retardation and religiosity. ${ }^{13,14}$

Eachindividual hasabio-psycho-socio-religiousspiritual aspect, so psychiatric disorder must be managed holistically and eclectically. ${ }^{19}$ Background religious and cultural beliefs of mothers determine maternal coping adjusting to negative situations. ${ }^{15,16}$ When in a state of helplessness and hopelessness, mothers who have religious beliefs tend to use religious coping. ${ }^{17}$ According to a study in Pakistan, religious coping is one of the coping strategies that is often used by mothers of children with mental retardation. ${ }^{18}$ With the background of a religious Indonesian society, it is assumed that the religiosity factor plays a role in the use of coping strategies for mothers of children with mental retardation in Indonesia. So far, research related to the aspect of religiosity in the realm of psychiatry is still lacking. Similar studies on the association between the use of religious coping and the psychological well-being of mothers of children with mental retardation have never been done in Indonesia. Based on the background above, the authors are interested in researching the association between the use of religious coping and the psychological well-being of mothers of children with mental retardation at the SLB Negeri 1 Bantul.

\section{Methods}

This is an analytic descriptive research with crosssectional design to determine the association between the use of religious coping with the psychological well-being of mothers of children with mental retardation. Whole sampling technique was used to collect subjects. The study was conducted at SLB Negeri 1 Bantul for 3 weeks in April 2019. Inclusion criteria included mothers who were the biological mother and caregivers of the children with a mild to moderate level of mental retardation aged 6-24 years old who study on SLB Negeri 1 Bantul. The participants were 108 mothers. All mothers who met the study criteria received an informed consent form before data was taken. If the mother was agreed in participating, a member of the research team met with the mother privately, answered questions, and collected the signed informed consent. After that, research team collect demographic data, independent variables (religious coping), dependent variables (psychological wellbeing), and confounding variables (mother's age, family income, marital status, mother's employment status, family income, children's gender, children's level of mental retardation and children's class grade) from all subjects who meet inclusion criteria.

Data was taken from subjects using some instruments included personal data questionnaires, the Indonesian version of Psychological Well Being Scale ( $r=0.314-0.745 ; \alpha=0.933$ ), and the Indonesian version of Religious Coping Scale $(r=$ $0.235-0.761 ; \alpha=0,948$ ). Data analysis technique was performed in univariate (descriptive), bivariate (Chi square test); multivariate (multiple logistic regression test) and significant if $p<0.05$. This study has been approved by the ethics committee with reference numbers KE/FK/0434/EC/2019.

\section{Results}

Characteristics of participants this study can be seen in tables 1 . Tables 2 shows characteristics of children with mental retardation on SLB Negeri 1 Bantul. Tables 3 and 4 show the distribution 
Table 1. Characteristics of mothers of children with mental retardation $(n=108)$

\begin{tabular}{lccc}
\hline \multicolumn{1}{c}{ Variable } & Mean \pm SD & f & $\%$ \\
\hline Mother's age (years) & $45.52 \pm 7.85$ & & \\
Mother's age category & & \\
$\quad$ Adult & 103 & 95.4 \\
$\quad$ Elder & 5 & 4.6 \\
Mother education & & \\
$\quad$ High & 62 & 57.4 \\
Low & 46 & 42.6 \\
Marriage status & & \\
$\quad$ Married & 96 & 88.9 \\
$\quad$ Widowed & 12 & 11.1 \\
Employment status & & \\
$\quad$ Employed & 65 & 60.2 \\
$\quad$ Unemployed & 43 & 39.8 \\
Family income & & \\
$\quad$ Low (< UMP) & 62 & 57.4 \\
High (> UMP) & 46 & 42.6 \\
Religion & & \\
$\quad$ Islam & 100 & 92.6 \\
Catholic & 4 & 3.7 \\
Christian Protestant & 4 & 3.7 \\
\hline
\end{tabular}

Table 2. Characteristics of children with mental retardation $(n=108)$

\begin{tabular}{lccc}
\hline \multicolumn{1}{c}{ Variable } & Mean \pm SD & $\mathbf{f}$ & $\%$ \\
\hline Age (years) & $14.12 \pm 3.98$ & & \\
Initial age study (years) & $7.89 \pm 2.81$ & & \\
Initial age diagnosed & & & \\
with mental & $4.77 \pm 3.39$ & & \\
retardation (years) & & & \\
Gender & & & \\
$\quad$ Boy & & 75 & 69.4 \\
$\quad$ Girl & & 33 & 30.6 \\
Level of mental & & \\
retardation & & 54 & 50.0 \\
$\quad$ Mild (class C) & & 54 & 50.0 \\
$\quad$ Moderate (class C1) & & & \\
Class level & & 58 & 53.7 \\
$\quad$ Primary school & & 30 & 27.8 \\
$\quad$ Junior high school & & 20 & 18.5 \\
\hline Senior high school & & & \\
\hline
\end{tabular}

frequency of religious coping and psychological well-being of mothers of children with mental retardation in SLB Negeri 1 Bantul.

The Chi square test results in table 5 shows a significant association between religious coping and the psychological well-being of mothers of children with mental retardation ( $X^{2}: 17.897 ; p: 0.000 ; 95 \%$ $\mathrm{Cl} 2.46$-12.92; RP: 5.65; C: 0.377). There is also a significant association between the five dimensions of religious coping with psychological well-being of mother of children with mental retardation in SLB Negeri 1 Bantul ( $p$ : 0.000), namely: dimensions of finding a meaning ( $\mathrm{X}^{2}: 13.412 ; \mathrm{p}: 0.000$; RP: 4.4; $\mathrm{Cl}$ 95\%: 1.95-9.82), dimensions of gain control ( $\mathrm{X}^{2}$ : 19.871; p: 0.000; RP: 6.33; 95\% Cl: 2.73-14.69), dimensions of gain comfort and closeness to God ( $X^{2}$ : 39.041; p: 0.000; RP: 17.6; 95\% Cl: 6.5347.45), dimension of gain intimacy with others and closeness to God ( $X^{2}$ : 14.656; p: 0.000; RP: 4.94; 95\% Cl: 2.12-11.49), and dimensions of achieving life transformation ( $\mathrm{X}^{2}: 14.948 ; \mathrm{p}: 0.000$; RP: 4.8; 95\% Cl: 2.12-10.86).

Only one confounding variable i.e maternal education has a significant association with psychological well-being of mothers $\left(X^{2}: 6.866\right.$; $C$ : 0.244; p: 0.009; RP: 2.86 ; $95 \% \mathrm{Cl}: 1.29-6.35)$. The bivariate analysis showed no statistically significant association $(p>0.05)$ between others confounding variables include mother's age, family income, marital status, mother's employment status, family income, children's gender, children's level of mental retardation and children's class grade with the psychological well-being of mothers of children with mental retardation (table 6).

The results of the logistic regression test on table 7 shows there are two variables that influence and have a significant association with psychological well-being of mothers of children with mental retardation, namely religious coping (p: 0.000 ; RP: 4.612; 95\% Cl: 1.960-10.852) and mother's education (p: 0.043; RP: $1.449 ; 95 \% \mathrm{Cl}$ : 1.011-2.078). Fit model as measured by Nagelkerke $R$ Square shows the value of $R^{2}=0.267$. This means that religious coping and mother's education have $26.7 \%$ effective contribution to the psychological well-being of mothers of children with mental retardation. The rest is explained by other variables that are not analyzed or examined. 
Table 3. The distribution frequency of the total religious coping \& dimensions of religious coping for mothers of children with mental retardation $(n=108)$

\begin{tabular}{|c|c|c|c|}
\hline Variable & Mean \pm SD & f & $\%$ \\
\hline Religious coping & $149.27 \pm 15.37$ & & \\
\hline High & & 53 & 49.1 \\
\hline Low & & 55 & 50.9 \\
\hline $\begin{array}{l}\text { Dimension of finding a } \\
\text { meaning }\end{array}$ & $20.60 \pm 2.51$ & & \\
\hline High & & 54 & 50.0 \\
\hline Low & & 54 & 50.0 \\
\hline $\begin{array}{l}\text { Dimension of gain } \\
\text { control }\end{array}$ & $37.26 \pm 4.71$ & & \\
\hline High & & 56 & 51.9 \\
\hline Low & & 52 & 48.1 \\
\hline $\begin{array}{l}\text { Dimension of gain } \\
\text { comfort and closeness } \\
\text { to God }\end{array}$ & $35.35 \pm 3.77$ & & \\
\hline High & & 59 & 54.6 \\
\hline Low & & 49 & 45.4 \\
\hline $\begin{array}{l}\text { Dimension of intimacy } \\
\text { with others and }\end{array}$ & $25.11 \pm 2.88$ & 41 & 38.0 \\
\hline $\begin{array}{l}\text { closeness to God } \\
\text { High } \\
\text { Low }\end{array}$ & & 67 & 62.0 \\
\hline $\begin{array}{l}\text { Dimension of achieving } \\
\text { life transformation }\end{array}$ & $30.94 \pm 3.96$ & & \\
\hline High & & 55 & 50.9 \\
\hline Low & & 53 & 49.1 \\
\hline
\end{tabular}

\section{Discussion}

Most respondents (50.9\%) have low religious coping where in the details of the dimensions of religious coping the majority of respondents had low scores on the dimension of gain intimacy with others and closeness to God (62\%). This means that most mothers still lack the intimacy with others with regard to support from religious members. However, all of respondents did not state that they received negative religious comments which blamed them for their condition. Some respondents stated that they had received support from religious communities, such as strengthening by religious leaders through special religious services for children with disabilities (Catholic) or tausyiah (Islam) regarding the condition of the child. Spirituality and religiosity are useful in mediating
Table 4. The distribution frequency of psychological well-being of mothers $(n=108)$

\begin{tabular}{llcc}
\hline \multicolumn{1}{c}{ Variable } & Mean \pm SD & $\mathbf{f}$ & $\%$ \\
\hline $\begin{array}{l}\text { Total psychological well- } \\
\text { being }\end{array}$ & $77.48 \pm 9.98$ & & \\
$\quad$ High & & 51 & 47.2 \\
$\quad$ Low & & 57 & 52.8 \\
Self acceptance & $18.08 \pm 3.01$ & & \\
$\quad$ High & & 47 & 43.5 \\
$\quad$ Low & & 61 & 56.5 \\
Positive relationships & $14.69 \pm 2.26$ & & \\
with others & & 52 & 48.1 \\
$\quad$ High & & 56 & 51.9 \\
$\quad$ Low & & & \\
Autonomy & $12.27 \pm 1.99$ & & \\
$\quad$ High & & 44 & 40.7 \\
$\quad$ Low & & 64 & 59.3 \\
Environmental mastery & $12.63 \pm 2.24$ & & \\
$\quad$ High & & 54 & 50.0 \\
$\quad$ Low & & 54 & 50.0 \\
Purpose in life & & & \\
$\quad$ High & $12.31 \pm 1.99$ & & 40.7 \\
$\quad$ Low & & 64 & 59.3 \\
$\begin{array}{l}\text { Personal growth } \\
\text { High } \\
\text { Low }\end{array}$ & $7.49 \pm 1.66$ & & \\
\hline & & 56 & 51.9 \\
& & 52 & 48.1 \\
\hline
\end{tabular}

stress and supporting mothers of children with disabilities. ${ }^{20}$

In table 3 shows $50 \%$ of respondents get balanced scores on dimensions of finding a meaning. This means that $50 \%$ of respondents can find the meaning and purpose of having children with mental retardation by the help of the values of religiosity beliefs, so they are able to accept the condition of the child. Every individual keeps trying to find the meaning of life, including mothers of children with mental retardation. The meaning associated with a situation is more influential than the situation itself. Mothers try to find support by switching to God and religion when facing situations that are unbearable, traumatic or fail to find solutions to problems. This is done as an effort to understand life and what has been passed so far. $^{21}$

Some respondents stated that the religious teachings they believed were the main basis for them to be able to understand the meaning of 
Table 5. Association between the dimensions of religious coping and the psychological well-being of mother of children with mental retardation

\begin{tabular}{|c|c|c|c|c|c|c|c|c|c|}
\hline \multirow{3}{*}{ Variable } & \multicolumn{9}{|c|}{ Psychological well-being } \\
\hline & \multicolumn{2}{|c|}{ Low } & \multicolumn{2}{|c|}{ High } & \multirow[t]{2}{*}{$x^{2}$} & \multirow[t]{2}{*}{ C } & \multirow[t]{2}{*}{$\mathbf{p}$} & \multirow[t]{2}{*}{$\mathbf{R P}$} & \multirow[t]{2}{*}{$\mathrm{Cl} 95 \%$} \\
\hline & $\mathbf{f}$ & $\%$ & f & $\%$ & & & & & \\
\hline \multicolumn{10}{|l|}{ Religious coping } \\
\hline Low & 40 & 72.7 & 15 & 27.3 & 17.897 & 0.377 & 0.000 & 5.65 & 2.47- \\
\hline High & 17 & 32.1 & 36 & 67.9 & & & & & 12.92 \\
\hline \multicolumn{10}{|c|}{ Dimension of finding a meaning } \\
\hline Low & 38 & 70.4 & 16 & 29.6 & 13.412 & 0.332 & 0.000 & 4.4 & $1.95-$ \\
\hline High & 19 & 35.2 & 35 & 64.8 & & & & & 9.82 \\
\hline \multicolumn{10}{|l|}{ Dimension of gain control } \\
\hline Low & 39 & 75.0 & 13 & 25.0 & 19.871 & 0.394 & 0.000 & 6.33 & $2.73-$ \\
\hline High & 18 & 32.1 & 38 & 67.9 & & & & & 14.69 \\
\hline \multicolumn{10}{|c|}{ Dimension of gain comfort and closeness } \\
\hline to God & 42 & 85.7 & 7 & 14.3 & 39.041 & 0.515 & 0.000 & 17.6 & $6.53-$ \\
\hline Low & 15 & 25.4 & 44 & 74.6 & & & & & 47.45 \\
\hline High & & & & & & & & & \\
\hline \multicolumn{10}{|c|}{$\begin{array}{l}\text { Dimension of gain intimacy with others and } \\
\text { closeness to God }\end{array}$} \\
\hline Low & 45 & 67.2 & 22 & 32.8 & 14.656 & 0.346 & 0.000 & 4.94 & $2.12-$ \\
\hline High & 12 & 29.3 & 29 & 70.7 & & & & & 11.49 \\
\hline \multicolumn{10}{|c|}{ Dimension of achieving life transformation } \\
\hline Low & 38 & 71.7 & 15 & 28.3 & 14.948 & 0.349 & 0.000 & 4.80 & 2.12- \\
\hline High & 19 & 34.5 & 36 & 65.5 & & & & & 10.86 \\
\hline
\end{tabular}

Analysis was performed using chi-square test. Significant $(p<0.05)$.

having children with mental retardation and this could calm them down. Religiosity is the basis of a general perspective and system of meaning to understand the daily experiences of life for most individuals. ${ }^{16}$ Religion seems to offer meaning to the misery and suffering of parents. With the religious perspective they have, the individual thinks that the world seems safe, fair, logical, harmonious, and finally can be controlled. Parents get hope, strength, and patience from the perspective of that religion. Respondents of this study stated the meaning of having children with mental retardation, namely: as blessed mothers, chosen by God, special mothers, children make mother's fortune increase, and children as tickets to heaven for them.

Most respondents received high scores on three dimensions of religious coping, namely: gain control (51.9\%), gain comfort and closeness to God (54.6\%), and achieving life transformation (50.9\%). This means that respondents have high environmental control abilities, feel comfort and closeness to God, and get a life transformation. Religiosity (religion) as a coping strategy for mothers can function to offer strength, empowerment and control in dealing with problems, so that mothers are able to gain the insight, protection, and assistance needed to achieve the results they feel unable to reach with their own strength. Religiosity can also help individuals reduce emotional burdens, thereby arousing emotional comfort through personal association $s$ with God. In addition, religiosity helps mothers surpass themselves and achieve self-growth. ${ }^{22}$

In table 4 shows $52.8 \%$ respondents in this study have a low total psychological well-being. Previous research also found that most mothers of children with mental retardation have low psychological well-being compared to mothers of normal children. ${ }^{5,23}$ Low psychological well-being will affect the child care process, which will result 
Table 6. Association of confounding variables with the psychological well-being of mothers of children with mental retardation

\begin{tabular}{|c|c|c|c|c|c|c|c|c|c|}
\hline \multirow{3}{*}{ Variable } & \multicolumn{9}{|c|}{ Psychological well-being } \\
\hline & \multicolumn{2}{|c|}{ Low } & \multicolumn{2}{|c|}{ High } & \multirow[t]{2}{*}{$x^{2}$} & \multirow[t]{2}{*}{ C } & \multirow[t]{2}{*}{$\mathrm{p}$} & \multirow[t]{2}{*}{$\mathrm{RP}$} & \multirow[t]{2}{*}{$\mathrm{Cl} 95 \%$} \\
\hline & $f$ & $\%$ & $f$ & $\%$ & & & & & \\
\hline \multicolumn{10}{|l|}{ Mother's age (f) } \\
\hline Adult & 55 & 53.4 & 48 & 46.6 & 0.343 & 0.056 & 0.665 & 1.72 & $0.27-10.2$ \\
\hline Elderly & 2 & 40.0 & 3 & 60.0 & & & & & \\
\hline \multicolumn{10}{|l|}{ Children gender (c) } \\
\hline Boy & 39 & 52.0 & 36 & 48.0 & 0.060 & 0.023 & 0.807 & 0.90 & $0.39-2.05$ \\
\hline Girl & 18 & 54.5 & 15 & 45.5 & & & & & \\
\hline \multicolumn{10}{|c|}{ Mental retardation level (c) } \\
\hline Mild & 28 & 51.9 & 26 & 48.1 & 0.037 & 0.019 & 0.847 & 0.93 & $0.44-1.97$ \\
\hline Moderate & 29 & 53.7 & 25 & 46.3 & & & & & \\
\hline \multicolumn{10}{|l|}{ Children class grade (c) } \\
\hline Low & 48 & 54.5 & 40 & 45.5 & 0.596 & 0.074 & 0.440 & 1.47 & $0.55-3.89$ \\
\hline High & 9 & 45.0 & 11 & 55.0 & & & & & \\
\hline \multicolumn{10}{|c|}{ Mother's education level (c) } \\
\hline Low & 31 & 67.4 & 15 & 32.6 & 6.866 & 0.244 & 0.009 & 2.86 & $1.29-6.35$ \\
\hline High & 26 & 41.9 & 36 & 58.1 & & & & & \\
\hline \multicolumn{10}{|l|}{ Marriage status (c) } \\
\hline Married & 51 & 53.1 & 45 & 46.9 & 0.042 & 0.020 & 0.838 & 1.13 & $0.34-3.76$ \\
\hline Widow & 6 & 50.0 & 6 & 50.0 & & & & & \\
\hline \multicolumn{10}{|c|}{ Mother's employment status (c) } \\
\hline Employed & 33 & 50.8 & 32 & 49.2 & 0.264 & 0.049 & 0.607 & 0.82 & $0.37-1.77$ \\
\hline Unemployed & 24 & 55.8 & 19 & 44.2 & & & & & \\
\hline \multicolumn{10}{|l|}{ Family income level (c) } \\
\hline Low & 37 & 59.7 & 25 & 40.3 & 2.780 & 0.158 & 0.095 & 1.92 & $0.88-4.17$ \\
\hline High & 20 & 43.5 & 26 & 56.5 & & & & & \\
\hline
\end{tabular}

in mothers feeling that caregiving is the thing must be done, feeling devastated in the present and life covered by the demands of nurturing. ${ }^{8}$

The results of the analysis prove that there is a significant association between religious coping and psychological well-being. These results are in accordance with other studies that also found a positive association between religiosity and psychological well-being. ${ }^{24}$ From the results of the Chi square test there was also a significant association between all dimensions of religious coping with psychological well-being of mothers of children with mental retardation in SLB Negeri 1 Bantul (table 5). The dimensions of religion and spirituality have a positive correlation with psychological well-being associated with selfactualization, meaning of life, and personal growth initiatives. ${ }^{25}$

The dimensions of attaining comfort and closeness to God have the highest closeness 
Table 7. The results of variable logistic regression tests related to the psychological well-being of mothers of children with mental retardation

\begin{tabular}{|c|c|c|c|c|c|c|c|c|c|}
\hline & \multirow{2}{*}{ Variabel } & \multirow{2}{*}{ B } & \multirow{2}{*}{ S.E. } & \multirow{2}{*}{ Wald } & \multirow{2}{*}{ df } & \multirow{2}{*}{ Sig. } & \multirow{2}{*}{$\operatorname{Exp}(B)$} & \multicolumn{2}{|c|}{ 95\% C.I for EXP(B) } \\
\hline & & & & & & & & Lower & Upper \\
\hline \multirow[t]{3}{*}{ Step $1^{a}$} & Religious coping & 1.529 & 0.437 & 12.263 & 1 & 0.000 & 4.612 & 1.960 & 10.852 \\
\hline & $\begin{array}{l}\text { Mother's education } \\
\text { level }\end{array}$ & 0.371 & 0.184 & 4.076 & 1 & 0.043 & 1.449 & 1.011 & 2.078 \\
\hline & Income & 0.158 & 0.469 & 0.114 & 1 & 0.736 & 1.171 & 0.467 & 2.937 \\
\hline \multirow[t]{2}{*}{ Step $2^{\mathrm{a}}$} & Religious coping & 1.528 & 0.436 & 12.261 & 1 & 0.000 & 4.609 & 1.960 & 10.840 \\
\hline & $\begin{array}{l}\text { Mother's education } \\
\text { level }\end{array}$ & 0.394 & 0.171 & 5.288 & 1 & 0.021 & 1.482 & 1.060 & 2.073 \\
\hline
\end{tabular}

association among other dimensions of religious coping ( $\left.X^{2}: 39.041 ; C: 0.515\right)$. This means that the dimension of religious coping which primarily helps reduce the emotional burden of mothers of children with mental retardation is to bring personal relationships closer to God. Religion can be a protective factor to counter the burden of parenting with mental retardation.

The results of the analysis of most confounding variables showed no significant association with the psychological well-being of mothers of children with mental retardation ( $p>0.05)$, except mother's education (table 6). Chi square test showed a significant association between maternal education and psychological well-being ( $p: 0.009$; RP: 2.86; $95 \% \mathrm{Cl}: 1.29-6.35)$. Multivariate analysis (table 7) also shows that education has effect to the psychological well-being of the mother ( $p: 0.043$; RP: 1.449; 95\% Cl: 1.011-2.078). Parents with higher education level report fewer child behavior problems, less burdened with higher parenting tasks and higher psychological well-being level than parents with low levels of education. ${ }^{26}$ Higher education can provide individual resilience in the face of stress, challenges and life difficulties. ${ }^{27}$

\section{Conclusion}

This study shows that religious coping is important to improve the psychological well-being of mothers of children with mental retardation. It is necessary to conduct collaboration between the Department of Psychiatry FK-KMK UGM with the SLB Negeri 1 Bantul to conduct counseling and psychoeducation for mothers who have low religious coping and psychological well-being. Psychoeducation is given by increasing intimacy with others and getting closer to personal relationships with God. Disdikpora DIY also should make promotional efforts to improve maternal psychological well-being. Other research is still needed to explore another issue on pychological well being of mothers of children with mental retardation.

\section{Acknowledgement}

We express our gratitude for all of research team, respondents, the teachers of SLB Negeri 1 Bantul, and Disdikpora Yogyakarta.

\section{Conflict of interest}

There is no conflict of interests. This study did not receive specific grants from funding agencies in the public sector, commercial, or non-profit section.

\section{References}

1. Mohan R, Kulkarni M. Resilience in Parents of Children with Intellectual Disabilities. Psychology and Developing Societies. 2018; 30(1): 19-43.

2. Cauda-laufer, N. 2017. Raising a Child with a Disability: Coping Mechanisms and Support Needs. PCOM Psychology Dissertations. 2017; 
432.

3. McConnell D, Savage A. Stress and Resilience Among Families Caring for Children with Intellectual Disability: Expanding the Research Agenda. Current Developmental Disorders Reports. 2012; 2(2): 100-109.

4. Chouhan CS, Singh P, Kumar S. Assessment of Daily Parenting Stress and Depressive Symptoms among Parents of Children with Intellectual Disability. International Multispecialty Journal of Health. 2016; 2(4): 2395-6291.

5. Vargas-Muñoz ME, López-Liria R, RocamoraPérez P, Aguilar-Parra JM, Díaz-López MP, Padilla-Góngora D. Maladjustment in Families with Disabled Children. Procedia-Social and Behavioral Sciences. 2017; 237: 863-868.

6. Parameswari S, Gnanajane EJOJ. A Study on Psychological Well Being among the Parents of Children with Intellectual and Developmental Disabilities. IOSR Journal of Humanities and Social Science. 2016; 8-12

7. Kishore MT. 2011. Disability Impact and Coping in Mothers of Children with Intellectual Disabilities and Multiple Disabilities. Journal of Intellectual Disabilities. 2011; 15(4), 241-251.

8. Simpson N, Mizen L, Cooper SA. Intellectual disabilities. Medicine. 2016; 44 (11): 679-682.

9. Wood A.M., \& Joseph S. The Absence of Positive Psychological (Eudemonic) Well-Being as A Risk Factor for Depression: A Ten Year Cohort Study. Journal Affective Disorder. 2010; 122: 213-7.

10. Beighton C, Wills J. Are Parents Identifying Positive Aspects to Parenting Their Child with An Intellectual Disability or Are They Just Coping? A Qualitative Exploration. Journal of Intellectual Disabilities. 2017; 21(4), 325-345.

11. Singh, KT, Panday P. Burden, Stress and Coping Strategies of Intellectually Disabled Children. The International Journal of Indian Psychology. 2015; 2(3): 2348-5396.

12. Faramarzi S. Comparing The Quality of Life and Psychological Well-Being in Mothers of Children With Hearing Loss and Mothers of Children with Other Special Needs. Aud Vest Res. 2017; 26 (2): 86-92.
13. Ajmal S, Javed S, Javed H. Association Study between Level of Psychological Well-Being and Social Support among Depressed and NonDepressed Women. International Journal of Humanities and Social Science. 2016; 6 (5), 161-164.

14. Batubara A. Hubungan Antara Religiusitas Dengan Psychological Well Being Ditinjau Dari Big Five Personality Pada Siswa SMA Negeri 6 Binjai. Jurnal Al-Irsyad. 2017; 7(1): 31-41.

15. Mirsaleh YR, Rezai H, Khabaz M, Ardekani IA, Abdi K. Personality Dimensions, Religious Tendencies and Coping Strategies as Predictors of General Health in Iranian Mothers of Children with Intellectual Disability: A Comparison with Mothers of Typically Developing Children. Journal of Applied Research in Intellectual Disabilities. 2011; 24: 573-582.

16. Sharak FM, Bonab BG, Jahed M. 2017. Association Between Stress and Religious Coping and Mental Health in Mothers with Normal and Intellectually Disabled Children. International Journal of Educational \& Psychological Research. 2017: 3: 198-204.

17. Krok D. The Role of Meaning in Life Within the Relations of Religious Coping and Psychological Well-Being. Journal of Religion and Health. 2015; 54: 2292-2308.

18. Sheikh MH, Ashraf S, Imran N, Hussain S, Azeem MW. Psychiatric Morbidity, Perceived Stress and Ways of Coping Among Parents of Children with Intellectual Disability in Lahore, Pakistan. Cureus. 2018; 10(2): e2200.

19. Soewadi S. Simtomatologi Dalam Psikiatri. Yogyakarta: Medika Fakultas Kedokteran Universitas Gadjah Mada. 1999

20. Pillay D, Girdler S, Collins M, Leonard H. It's not What You were Expecting, But It's Still a Beautiful Journey": The Experience of Mothers of Children with Down Syndrome. Disability \& Rehabilitation. 2012; 34(18): 1501-1510.

21. Hatun $O$, Yavuz-birben $F$, İnce $Z$, Gülay KY. The Ticket to Heaven: A Spiritual Resource for Coping with Disability. Spiritual Psychology and Counseling. 2016; 1: 209-235. 
22. Pargament K, Feuille M, Burdzy D. 2011. The Brief RCOPE: Current Psychometric Status of a Short Measure of Religious Coping. Religions. 2011; 2: 51-76

23. Boromand $\mathrm{N}$, Narimani $M$, Mosazadeh $T$. Comparing The Psychological Well Being Factor among The Parents of The Mentally Retarded Children With Those of The Normal Children. International Letters of Social and Humanistic Sciences. 2014; 21 : 1-8.

24. Ismail Z, Desmukh S. Religiosity and Psychological Well-Being. International Journal of Business and Social Science: 2012; 3 (11): 20-28.

25. Ivtzan I, Chan CPL, Gardner HE, Prashar
K. Linking Religion and Spirituality with Psychological Well-being: Examining Selfactualisation, Meaning in Life, and Personal Growth Initiative. Journal of Religion \& Health [Internet]. Springer Nature. 2011; 52(3): 915929.

26. Cramm JM, Nieboer AP. Psychological Wellbeing of Caregivers of Children with Intellectual Disabilities: Using Parental Stress as A Mediating Factor. Journal of Intellectual Disabilities. 2011; 15(2): 101-113.

27. Ryff CD. Psychological Well-Being Revisited: Advances in the Science and Practice of Eudaimonia. Psychotherapy and Psychosomatics. 2014; 83: 10-28. 